\title{
Study Effect of Powder Protein Intake on Total Protein and Creatinine Concentrations in Blood of Bodybuilder
}

\author{
Karzan A. Omar1*, Razhan S. Othman², Abubakir S. Ismail ${ }^{3}$ \\ ${ }^{1}$ Department of Chemistry, Koya University, Koya, Iraq \\ ${ }^{2}$ Department of Medical Laboratory Technique, Hawler Polytechnic University, Shaqlawa, Iraq \\ ${ }^{3}$ Department of Biology, Salahadden University, Erbil, Iraq \\ Email: ${ }^{*}$ karzan.abdulkareem@koyauniversity.org
}

Received 28 January 2016; accepted 13 February 2016; published 18 February 2016

Copyright (C) 2016 by authors and OALib.

This work is licensed under the Creative Commons Attribution International License (CC BY).

http://creativecommons.org/licenses/by/4.0/

(c) (i) Open Access

\section{Abstract}

The powder protein is mostly used as the main dietary by bodybuilders for improving exercise training. This research studied the effect of the powder protein intake on serum total protein and creatinine concentrations, and urine $\mathrm{pH}$ and protein of three different groups. The serum total protein concentration has no relationship with the amount of powder protein intake and cannot be affected by it. But the serum creatinine concentration has a direct relationship with the amount of powder protein intake. The group $A$ and $B$ serum creatinine concentrations in their blood were abnormal due to lack in the amount of protein intake in their daily life and exercise. The group $\mathrm{C}$ used sufficient amounts of powder protein $1.2-1.4 \mathrm{gm} / \mathrm{Kg} / \mathrm{day}$, which maintained their creatinine concentration. This quantity of protein intake for bodybuilders is not only safe, but also is improved the training adaptations in their excises training. The urine tests indicated no significant differences $(\mathrm{P}<0.01)$ between their $\mathrm{pH}$ and at the same time the trace amount of protein in some of individuals urine was observed.

\section{Keywords}

Powder Protein, Serum Total Protein Concentration, Serum Creatinine Concentration, Urinary Protein

Subject Areas: Food Science \& Technology

\section{Introduction}

Protein intake is one of the important nutrients for building and maintaining all types of body parts including

${ }^{*}$ Corresponding author.

How to cite this paper: Omar, K.A., Othman, R.S. and Ismail, A.S. (2016) Study Effect of Powder Protein Intake on Total Protein and Creatinine Concentrations in Blood of Bodybuilder. Open Access Library Journal, 3: e2374.

http://dx.doi.org/10.4236/oalib.1102374 
muscles, bones, hair, and nails. Proteins are aggregates of amino acids that are essential component for muscle growth. Therefore, both athletes and non-athletes need these amino acids to get strength and masculine to protect the body from infection and allow circulating the fluids in the body. Athletes for maintaining their energy balance and growing muscle, have to consume the proper amount of rich food protein such as egg, milk, meat and fish [1]-[3]. They provide the highest quality rating of food sources and vegetables which require consuming different types for getting sufficient quantity of protein. Also the powder protein is commonly used by athletes or active individuals who engage in exercise, sport training and bodybuilding such as mass gain protein, whey protein and other different types of the powder proteins which contain sufficient quantity of protein for increasing muscle synthesis more than other proteins which gain from animal and vegetarian source [4]. Therefore, most of the athletes or active individuals who engage in exercise, sport training and bodybuilding use powder protein for increasing muscle tissue strength that requires an extra energy intake than daily energy expenditure. As a result, many studies have determined that the average protein intake for endurance athletes or active individuals who engage in exercise, sport training and bodybuilding should be between $1.2-1.4 \mathrm{~g} / \mathrm{kg} / \mathrm{day}$ to ensure a positive nitrogen balance [5]-[8] and for non-athletes should be between $0.8-1.0 \mathrm{gm} / \mathrm{kg} / \mathrm{day}$ [9]. Mostly excess amount of protein intake is used to provide energy, and once energy requirements are met, surplus protein intake may be stored as body fat. The powder protein becomes a popular protein source for people trying to improve athletic performance and build muscle mass. Although there is an opinion about side-effects of powder protein intake on health and may be damaging the kidney. Therefore, in this research, we studied the total serum protein and serum creatinine concentrations of 75 volunteers along with their urine concentration to reveal the effect of powder protein intake on their serum total protein and creatinine concentrations comparable to bodybuilders and non-bodybuilders who don't use powder proteins, but only take their protein requirement from foods.

\section{Material and Method}

Fifty healthy bodybuilders and 25 non-bodybuilders were selected on their medical history with no kidney problems participated in this study (mean \pm SD; age: $24.84 \pm 4.8$ year; height: $169.93 \pm 3.4 \mathrm{~cm}$; weight: $76.92 \pm$ $11.4 \mathrm{~kg})$. Subjects were equally divided into three groups, group $\mathrm{A}(\mathrm{n}=25)$ non-bodybuilders, group $\mathrm{B}(\mathrm{n}=25)$ bodybuilders without using powder protein and group $C(n=25)$ bodybuilders using powder protein in their exercise. Participants were healthy, trained bodybuilders and non-bodybuilders. Regularly bodybuilders training 4 - 6 days per week whiles the non-bodybuilders do not participate in any kind of exercise. Blood samples were taken by venipuncture and collected in polystyrene tubes. All laboratory analysis was carried out in the biochemistry laboratory of Banaslawa. Plasma was obtained by centrifugation for 15 minutes. Samples of each group were tested repeatedly for three times within 3 hours and urine samples were collected and measured at the same time for urinary protein and $\mathrm{pH}$ tests. Serum total protein and creatinine concentrations were determined by using standard methods of Biuret and Kinetic, $\mathrm{pH}$ and protein in urine by the CYBOW strip kit. Reagents, standards and Calibrators were purchased from Almusanada Scientific (Alatebaa Street, Alnoor Building).

\section{Statistical Analysis}

Characteristics of the groups and their serum total protein, serum creatinine concentration and urinary $\mathrm{pH}$ were compared by using $\mathrm{T}$-test at a significance level of $\mathrm{P}<0.01$. All data are presented asmeans \pm standard deviation of the mean (SD).

\section{Results}

Seventy five subjects were recruited for this study, including fifty bodybuilder and twenty five non-bodybuilder healthy individuals participated in this study (mean \pm SD; age: $24.85 \pm 4.8$ year; height: $169.93 \pm 3.4 \mathrm{~cm}$; weight: $76.92 \pm 11.4 \mathrm{~kg} ; 75$ male). There were no such differences $(\mathrm{P}<0.01)$ between characteristics of groups as shown in Table 1.

Also, no significant differences $(\mathrm{P}<0.01)$ observed between the serum total protein concentrations of all three groups, but there were significant differences $(\mathrm{P}<0.01)$ of serum creatinine concentration between groups of A and B compared with group C as shown in Table 2.

The urine tests indicated that there were no significant differences $(\mathrm{P}<0.01)$ between a $\mathrm{pH}$ of their urine tests at the same time the trace of protein in the urine of some volunteers observed as shown in Table 3. 
Table 1. Subject characteristics.

\begin{tabular}{cccc}
\hline Groups & Age year & Height cm & Weight kg \\
\hline A (25 male) & $22 \pm 2.3$ & $169 \pm 2.8$ & $73.42 \pm 11.1$ \\
B (25 male) & $24.85 \pm 5.5$ & $170 \pm 1.5$ & $76.95 \pm 12.4$ \\
C (25 male) & $27.91 \pm 4.9$ & $170 \pm 3.2$ & $80.5 \pm 9.5$ \\
\hline
\end{tabular}

Data are mean \pm SD

Table 2. Comparison of serum total protein and creatinine concentration between subjects.

\begin{tabular}{ccc}
\hline Groups & Serum total protein g/dL & Serum creatinine mg/dL \\
\hline A (25 male) & $6.75 \pm 0.9$ & $0.76 \pm 0.1$ \\
B (25 male) & $6.95 \pm 0.5$ & $0.77 \pm 0.3$ \\
C (25 male) & $6.82 \pm 0.65$ & $1.02 \pm 0.3$ \\
\hline
\end{tabular}

Data are mean \pm SD. Serum Total Protein concentration range $(6.4-8.3 \mathrm{~g} / \mathrm{dL})$ and Serum Creatinine concentration range $(0.9-1.3 \mathrm{mg} / \mathrm{dL})$.

Table 3. Comparison of urinary $\mathrm{pH}$ and protein between subjects.

\begin{tabular}{ccc}
\hline Groups & $\mathrm{pH}$ & Trace of protein $^{*}$ \\
\hline A (25 male) & $6.03 \pm 0.7$ & 2 \\
B (25 male) & $6.17 \pm 0.3$ & 6 \\
C (25 male) & $6.03 \pm 0.7$ & 9 \\
\hline
\end{tabular}

Data are mean \pm SD. ${ }^{*}$ Number of persons has protein in their urine.

\section{Discussions}

The purpose of the present research is study effect of powder protein intake on serum total protein and creatinine concentrations of bodybuilders and compared to bodybuilders and non-bodybuilders are not using powder protein. The serum total protein concentration measured for all three groups by spectrophotometer was observed no significant differences $(\mathrm{P}<0.01)$ between them and the results of all three groups was in range. While there were significant differences $(\mathrm{P}<0.01)$ observed in serum creatinine concentration between group A and B compared with group C. The average results of group A and B were out of range and group C was in the normal range. The results show that there is no relationship between intake powder proteins with serum total protein concentration and powder protein intake has no effect on serum total protein concentration in blood. But there is a strong relationship between intakes of powder protein with serum creatinine concentrations. In the test results of group A and B, the sign of insufficient of protein intake observed, which is usually caused by low serum creatinine concentration while the group $\mathrm{C}$ intake a sufficient amount of powder protein approximately $1.2-1.4$ $\mathrm{gm} / \mathrm{Kg} /$ day. Therefore, the serum creatinine concentration of group $\mathrm{C}$ in a normal and abnormal in both groups of $\mathrm{A}$ and $\mathrm{B}$ for this reason, they have to intake proper amount of protein until their serum creatinine concentration reaches to normal range to prevent any damage may cause to their kidney because of lower protein intake. It indicated the low and high protein intake within the time has a negative effect on the kidney of trained bodybuilders and non-bodybuilders.

The results of the urine test indicated no significant differences $(\mathrm{P}<0.01)$ between a $\mathrm{pH}$ of the groups and the presence of trace amount of protein in their urine are not concerned because it is usually occurs under several conditions such as cold exposure, emotional stress, heat exposure and strenuous exercise. Therefore, these conditions do not indicate kidney damage.

\section{Conclusion}

This is the first study done on the effect of powder protein intake on serum total protein and creatinine concen- 
trations in blood of bodybuilders and compared with bodybuilders and non-bodybuilders who don't use powder proteins. The volunteers participated in this study, did not have any history of kidney and liver problems and they are medically free of any diseases. It showed intake of powder proteins and other kinds of protein did not have any effect on the serum total protein concentration. However, the quantity of powder protein intake had an effect on the serum creatinine concentration, which was clearly obvious in the group C. They consumed an average intake of powder proteins $1.2-1.4 \mathrm{gm} / \mathrm{Kg} /$ day. Their serum creatinine concentration was in a normal range, but within the time and by using extra amounts of protein powder may be an effect on their serum creatinine concentration and damage their kidneys. Also, even insufficient amounts of protein intake have an effect on serum creatinine concentration and kidney function. The urine tests indicated no significant differences in $\mathrm{pH}$, but some differences were observed in protein urea which was present in trace amounts in the urine of some individuals of each group.

\section{Acknowledgements}

The authors are grateful to the Capitan Kamaran owner of Golden gym and his associates Mr. Hiwa and Mr. Sherwan for their supports and cooperation.

\section{References}

[1] Campbell, W.W., Barton, M.L., Cyr-Campbell, D., Davey, S.L., Beard, J.L., Parise, G. and Evans, W.J. (1999) Effects of an Omnivorous Diet Compared with a Lactoovovegetarian Diet on Resistance-Training-Induced Changes in Body Composition and Skeletal Muscle in Older Men. American Journal of Clinical Nutrition, 70, 1032-1039.

[2] Godfrey, K., Robinson, S., Barker, D.J. and Osmond, C. (1996) Maternal Nutrition in Early and Late Pregnancy in Relation to Placental and Fetal Growth. Cox VBMJ, 312, 410-414.

[3] Pannemans, D.L., Wagenmakers, A.J., Westerterp, K.R., Schaafsma, G. and Halliday, D. (1998) Effect of Protein Source and Quantity on Protein Metabolism in Elderly Women. American Journal of Clinical Nutrition, 68, 12281235.

[4] Tang, J.E., Moore, D.R., Kujbida, G.W., Tarnopolsky, M.A. and Phillips, S.M. (2009) Ingestion of Whey Hydrolysate, Casein, or Soy Protein Isolate: Effects on Mixed Muscle Protein Synthesis at Rest and Following Resistance Exercise in Young Men. Journal of Applied Physiology, 107, 987-992. http://dx.doi.org/10.1152/japplphysiol.00076.2009

[5] Freidman, J.E. and Lemon, P.W.R. (1989) Effect of Chronic Endurance Exercise on the Retention of Dietary Protein. International Journal of Sports Medicine, 10, 118-123. http://dx.doi.org/10.1055/s-2007-1024886

[6] Lemon, P.W.R. (1995) Do Athletes Need More Dietary Protein and Amino Acids? International Journal of Sport Nutrition, 5, S39-S61.

[7] Meredith, C.N., Zackin, M.J., Frontera, W.R. and Evans, W.J. (1989) Dietary Protein Requirements and Protein Metabolism in Endurance-Trained Men. Journal of Applied Physiology, 66, 2850-2856.

[8] Tarnopolsky, M.A., MacDougall, J. and Atkinson, S. (1988) Influence of Protein Intake and Training Status on Nitrogen Balance and Lean Body Mass. Journal of Applied Physiology, 64, 187-193.

[9] Fulgoni, V.L. (2003) Current Protein Intake in America: Analysis of the National Health and Nutrition Examination Survey. American Journal of Clinical Nutrition, 87, 1554S-1557S. 